\title{
Prevalence of five tick-borne bacterial genera in adult Ixodes scapularis removed from white-tailed deer in western Tennessee
}

\author{
Sarah E Mays ${ }^{1}$, Brian M Hendricks ${ }^{1}$, David J Paulsen ${ }^{1}$, Allan E Houston ${ }^{2}$ and Rebecca T Trout Fryxell ${ }^{*}$
}

\begin{abstract}
Background: In the northeastern and midwestern regions of the United States Ixodes scapularis Say transmits the causal agents of anaplasmosis (Anaplasma phagocytophilum), babesiosis (Babesia microti), and borreliosis (Borrelia burgdorferi and B. miyamotoi). In the southeastern United States, none of those pathogens are considered endemic and two other tick-borne diseases (TBDs) (ehrlicihosis and rickettiosis) are more common. Our objective was to determine baseline presence and absence data for three non-endemic bacterial agents (Anaplasma, Borrelia and Babesia) and two commonly reported bacterial agents (Ehrlichia, and Rickettsia) in southern I. scapularis $(n=47)$ collected from 15 hunter-harvested white-tailed deer (Odocoileus virginianus) in western Tennessee.
\end{abstract}

Findings: Of the 47 ticks, 27 tested PCR positive for non-pathogenic Rickettsia species, two for Ehrlichia ewingii, one for Ehrlichia sp. "Panola Mountain", and one for Anaplasma phagocytophilum variant 1 strain. None of these ticks were positive for Babesia or Borrelia (including B. burgdorferi).

Conclusions: Finding human pathogens in host-fed I. scapularis merits additional studies surveying pathogen prevalence in questing ticks. Collection of questing I. scapularis in their peak activity months should be undertaken to determine the overall encounter rates and relative risk of pathogenic Ehrlichia in southern I. scapularis. Ehrlichia sequences were homologous to previous human isolates, but neither Babesia nor B. burgdorferi were identified in these ticks. With the identification of pathogenic bacteria in this relatively small collection of I. scapularis from western Tennessee, the study of the absence of Lyme disease in the south should be refocused to evaluate the role of pathogenic Ehrlichia in southern I. scapularis.

Keywords: Ixodes scapularis, Tennessee, Tick-borne disease, Anaplasma, Babesia, Borrelia, Ehrlichia, Rickettsia

\section{Findings}

Ixodes scapularis Say (blacklegged tick) is known to transmit the causal agents of many diseases causing illness and death in humans, livestock, pets, and wildlife [1]. These diseases include anaplasmosis, babesiosis and Lyme borreliosis [2-5]. Ehrlichiosis is another notable tick-borne disease (TBD), and although the causal agents Ehrlichia chaffeensis and E. ewingii have not been reported in I. scapularis in the U.S., an Ehrlichia muris-like species has been isolated from I. scapularis [6], and pathogenic Ehrlichia species have been found in other members of the I. ricinus complex, such as I. pacificus in California [7,8], I. ricinus in Russia

\footnotetext{
* Correspondence: RFryxell@utk.edu

${ }^{1}$ Department of Entomology and Plant Pathology, University of Tennessee, 370 Plant Biotechnology Building 2505 E J Chapman Drive, Knoxville, TN, USA Full list of author information is available at the end of the article
}

[9], and I. persulcatus in Korea [10]. Ixodes scapularis has also previously been shown to be infected with spotted fever group Rickettsia (SFGR) species of undetermined pathogenicity [11].

In Tennessee, Lyme disease is considered non-endemic; consequently, it is not likely to pose a high risk for human infection $[12,13]$. Other TBDs have a greater prevalence in Tennessee, including ehrlichiosis and rickettsiosis, with Rocky Mountain spotted fever (RMSF) being the most highly-reported TBD in the state [14-16] and TBD diagnoses has been increasing steadily in Tennessee for approximately the last 5 years [16]. While I. scapularis frequently bites humans in northeastern and midwestern states, it is less common in southeastern states and rarely encountered on humans during summer months [17]. There is still a critical need to characterize the 
potential causal agents in I. scapularis and corroborate findings that $B$. burgdorferi is rare in the southeast; consequently, we attempt to think "beyond Lyme" as described in Stromdahl and Hickling [17] within southeastern collected I. scapularis. The objective of this study was to determine baseline presence and absence data for three non-endemic bacterial agents (Anaplasma, Borrelia and Babesia) and two commonly reported bacterial agents (Ehrlichia, and Rickettsia) in I. scapularis collected from white-tailed deer.

In the fall of 2011 and 2012, 17 ticks (9 engorged) were collected from 6 deer, and 30 ticks (14 engorged) were collected from 9 deer, respectively, for a total of 47 adult I. scapularis ( 21 males and 26 females) from 15 white-tailed deer harvested at Ames Plantation Research and Education Center located in southwestern Tennessee. In the laboratory, ticks were identified to life stage, species, and sex [18]. Each specimen was bisected longitudinally with a sterile scalpel blade. Half of each tick was placed in $80 \%$ ethanol and stored at $-20^{\circ} \mathrm{C}$ as a voucher specimen. From the remaining half of each tick, total genomic DNA was extracted using a Fermentas DNA extraction kit (Thermo Scientific, Pittsburg, PA). Extracted DNA was stored at $-20^{\circ} \mathrm{C}$ in elution buffer until screening. Extracted DNA was screened with $16 \mathrm{~S}$ primers [19] to verify that extraction was successful and samples that could not be morphologically identified were $16 \mathrm{~S}$ sequenced (these samples were confirmed as 99\% homologous to I. scapularis GenBank L43855).

All 47 samples were screened for infection with Anaplasma, Babesia, Borrelia, Ehrlichia and Rickettsia species using genus-specific PCR reactions with positive and negative (sterile water) controls. Anaplasma and Ehrlichia species were amplified using groEL primers in a nested PCR [20] with a positive control of E. chaffeensis amplified from extracted tick DNA (94\% homologous to GenBank L10917). Primers for $16 S$ rRNA were used to identify Anaplasma strains [21]. For Babesia, the genus specific primers for NSS were qPCR-amplified [22] with a positive control of B. canis amplified from extracted dog DNA. Due to the controversy and discrepancy with Borrelia amplification and identification [23,24], we amplified $23 S$ using a real-time PCR [25] and flaB using a nested PCR (280 F and 754R outer reaction primers, and $301 \mathrm{~F}$ and 737R nested reaction primers) [26]. Positive controls were a B31-strain of B. burgdorferi for the $23 S$ real-time PCR reaction, and $B$. burgdorferi for the flaB nested PCR. For Rickettsia identification, PCR was used to amplify the ompA gene [27] with a positive control of an uncultured Rickettsia sp. amplified from extracted tick DNA (99\% homologous to GenBank HM446484). General and nested PCR reactions consisted of a $50 \mu \mathrm{l}$ reaction of $5 \mu \mathrm{l}$ extracted DNA ( $2 \mu \mathrm{l}$ of initial reaction for nested reaction), $25 \mu \mathrm{l}$ of Maxima Hot Start Green PCR Master
Mix (Thermo Scientific, Waltham, MA), and $18 \mu \mathrm{l}$ of nuclease free water. The initial Borrelia flaB PCR consisted of a $27 \mu \mathrm{l}$ reaction of $2 \mu \mathrm{l}$ extracted DNA ( $1 \mu \mathrm{l}$ of initial reaction for nested reaction), $12 \mu \mathrm{l}$ of Hot Start Master Mix, and $11 \mu \mathrm{l}$ of nuclease free water. PCR products were run on a $1.5 \%$ agarose gel stained with ethidium bromide. For qPCR of Borrelia 23S, a $20 \mu \mathrm{l}$ reaction of $2 \mu \mathrm{l}$ extracted DNA, $10 \mu \mathrm{l}$ Taq Polymerase (Applied Biosystems, Grand Island, NY), $0.4 \mu \mathrm{l}$ ROX (Applied Biosystems, Grand Island, NY) and $6.6 \mu \mathrm{l}$ of nuclease free water was used. DNA extractions, PCR amplification, and gel electrophoresis were carried out in different locations with dedicated equipment and reagents to prevent contamination.

To remove excess primers and nucleotides from positive samples, positive amplicons were cleaned with ExoSAP-IT (Affymatrix, Inc., Cleveland, $\mathrm{OH}$ ). The University of Tennessee Molecular Biology Resource Facility then bi-directionally sequenced the cleaned products. Sequence results were initially cleaned using Sequencher (Gene Codes Corporation, Ann Arbor, MI) and aligned with ClustalW in BioEdit (Ibis Biosciences, Carlsbad, CA). Sequences published in GenBank were used for genetic comparisons and to determine species identity. Phylogenetic trees based on Bayesian analyses were created using Bayesian Evolutionary Analysis Sampling Trees (BEAST) 1.7.5 and Fig Tree software [28] to display the associations between the amplified sequences and GenBank-published sequences.

Of the 47 I. scapularis collected in western Tennessee, only 20 were not PCR positive for one of the five different bacterial genera tested (Table 1). None of the ticks tested were PCR positive for Babesia species and none of these ticks were positive for Borrelia using the $23 \mathrm{~s}$ qPCR. Initially, B. burgdorferi sensu lato PCR with flaB primers yielded 13 positive results. These 13 amplicons were sequenced to confirm positivity, but sequencing yielded broken fragments and unamplified sequence products. We then repeated the assay for those 13 samples and found the results to be inconsistent (i.e., negatives when once positive, or inconsistent band sizes and numbers), and thus, failed to confirm the initial suspect-positives. In both flaB reactions, the banding patterns of unknown tick samples were faint and sequencing attempts on those bands yielded small fragments (e.g., sequence results appeared as "NNNN..."). The positive controls in this assay produced strong bands that were successfully sequenced, indicating that the reaction worked. Comparing the concentration of Borrelia-nested flaB amplicons to other similar assays, the concentration sent for sequencing with flaB ranged from 0 to $12 \mathrm{ng} / \mu \mathrm{L}$, while Ehrlichia nested concentration results ranged from 45 to $70 \mathrm{ng} / \mu \mathrm{L}$. The low concentration of amplified Borrelia flaB (range: 0 to $12 \mathrm{ng} / \mu \mathrm{L}$ ), the faint sample bands and strong control bands, the negative $23 \mathrm{~S}$ qPCR, and the low annealing 
Table 1 PCR results of adult Ixodes scapularis $(n=47)$ collected from 15 white-tailed deer harvested at AMES ${ }^{1}$

\begin{tabular}{|c|c|c|c|c|c|c|c|}
\hline \multirow{2}{*}{$\begin{array}{l}\text { Ixodes } \\
\text { scapularis }\end{array}$} & \multirow{2}{*}{$\begin{array}{l}\text { No. screened } \\
\text { (Male/Female) }\end{array}$} & \multicolumn{6}{|c|}{ Bacterial genera screened } \\
\hline & & $\begin{array}{l}\text { Anaplasma } \\
\text { spp. (\% Pos.) }\end{array}$ & $\begin{array}{l}\text { Babesia } \\
\text { spp. (\% Pos.) }\end{array}$ & $\begin{array}{l}\text { Borrelia } \\
\text { spp. (\% Pos.) }\end{array}$ & $\begin{array}{l}\text { Ehrlichia } \\
\text { spp. (\% Pos.) }\end{array}$ & $\begin{array}{l}\text { Rickettsia } \\
\text { spp. (\% Pos.) }\end{array}$ & $\begin{array}{l}\text { Total positive } \\
\text { (\% Pos.) }\end{array}$ \\
\hline \multicolumn{8}{|c|}{ Ixodes scapularis collected from white-tailed deer in 2011} \\
\hline Engorged & $0 / 9$ & $0 / 1$ & $0 / 0$ & $0 / 0$ & $0 / 0$ & $0 / 8$ & $0 / 9$ \\
\hline Crawling & $8 / 0$ & $0 / 0$ & $0 / 0$ & $0 / 0$ & $0 / 0$ & $2 / 0$ & $2 / 0$ \\
\hline Total & 17 & $1(5.9 \%)$ & $0(0 \%)$ & $0(0 \%)$ & $0(0 \%)$ & $10(58.8 \%)$ & $11(64.7 \%)$ \\
\hline \multicolumn{8}{|c|}{ Ixodes scapularis collected from white-tailed deer in 2012} \\
\hline Engorged & $0 / 14$ & $0 / 0$ & $0 / 0$ & $0 / 0$ & $0 / 3$ & $0 / 14$ & $0 / 17$ \\
\hline Crawling & $12 / 4$ & $0 / 0$ & $0 / 0$ & $0 / 0$ & $0 / 0$ & $1 / 2$ & $1 / 2$ \\
\hline Total & 30 & $0(0 \%)$ & $0(0 \%)$ & $0(0 \%)$ & $3(10.0 \%)$ & $17(56.7 \%)$ & $20(66.7 \%)$ \\
\hline \multicolumn{8}{|c|}{ Total Ixodes scapularis collected from AMES white-tailed deer } \\
\hline Engorged & $0 / 23$ & $0 / 1$ & $0 / 0$ & $0 / 0$ & $0 / 3$ & $0 / 22$ & $0 / 26$ \\
\hline Crawling & $20 / 4$ & $0 / 0$ & $0 / 0$ & $0 / 0$ & $0 / 0$ & $3 / 2$ & $3 / 2$ \\
\hline Total & 47 & $1(2.1 \%)$ & $0(0 \%)$ & $0(0 \%)$ & $3(6.4 \%)$ & $27(57.4 \%)$ & $31(66.0 \%)$ \\
\hline
\end{tabular}

${ }^{1}$ Ticks were either classified as engorged (attached with mouthparts in the host animal's skin through physical evidence such as tissue attached to mouthparts and/or expanded idiosoma) or crawling (attached on the host, but no physical evidence of feeding). Primers targeted groEL for Anaplasma and Ehrlichia spp, NSS for Babesia spp, 235 and flaB for Borrelia spp, and ompA for Rickettsia spp.

The total number positive in this table shows the number of PCR-positive results (including co-infections); consequently, the total number of infections exceeds the total number of positive ticks.

temperatures for the flaB assay $\left(52^{\circ} \mathrm{C}\right.$ ) (which may permit unspecific binding) indicate those 13 samples were likely negative. Given the low sample size we may not have screened enough ticks to detect Borrelia in western Tennessee, rather we would need to screen $\sim 400$ specimens from a population of 1000 I. scapularis to find a positive sample if $1 \%$ are considered positive at a $99 \%$ confidence level. Previously, 883 I. scapularis from hunterharvested deer from throughout Tennessee were screened for Borrelia species. None of the ticks were positive for $B$. burgdorferi and only one was positive for $B$. miyamoto $i$ [13], now considered a human pathogen $[29,30]$. There is much controversy surrounding the status of $B$. burgdorferi in the southern U.S. Recently the potential role of $A$. americanum in Lyme-like illnesses in the south intensified due to a report identifying DNA sequence evidence of Borrelia species infection in humans and ticks in the southern U.S. [26]. This study attempted to detect B. burgdorferi s.l. using the same assays [26], but in the confirmed Borrelia vector I. scapularis, the results of which indicted no Borrelia in southeastern I. scapularis ticks.

A total of 27 ticks (57.4\%) were PCR positive for three different non-pathogenic Rickettsia species (Figure 1). Twenty-four were greater than $98 \%$ homologous to an $I$. scapularis endosymbiont (GenBank EF689735), two were greater than 98\% homologous to an uncultured Rickettsia species (GenBank HM446484), and one was 99\% homologous to R. amblyommii (GenBank JF694090). Due to its branch location in relation to $R$. amblyommii samples, it is likely that both the reference sequence for an uncultured Rickettsia spp. (GenBank HM446484) and the samples homologous to it are $R$. amblyommii, especially since these sequences were identical to the $R$. amblyommii reference sequence (GenBank JF694090) over a 380 bp region.

Although the pathogenicity of many SFGR remains undetermined, the high rates of PCR positive samples with apparently non-pathogenic SFGR has been speculated to interfere with vertical transmission of pathogenic Rickettsia species (such as $R$. rickettsii) and potentially reduce the risk of human rickettsiosis [4,31-34], especially since this appears to be the case for D. variabilis [35].

Four ticks (8.5\%) produced amplicons for groEL, which were homologous to either Anaplasma species, or to Ehrlichia species that have been implicated as causal agents of human disease. All four of these ticks were females and at least partially engorged, suggesting the ticks acquired the bacteria from their white-tailed deer host (Table 1). One tick from 2011 had a groEL amplicon $99 \%$ homologous to A. phagocytophilum previously amplified from humans (GenBank U96728, AF033101, AF172159, AF172163 and KF015601) (Figure 1); however, subsequent testing with the $16 S$ rRNA primers identified it as the AP-variant 1 strain (100\% homologous to GenBank AJ242784), which is not considered likely to infect humans [36]. Two ticks from 2012 were 100\% homologous to E. ewingii previously amplified from a human patient (GenBank AF195273). One tick from 2012 was 100\% homologous to Ehrlichia sp. "Panola Mountain" (PME) previously amplified from A. americanum (GenBank HQ658904) (Figure 1). Of interest to the Tennessee region, this is the first report of PME and E. ewingii PCR-amplified from an I. scapularis. All of the four ticks PCR positive for 

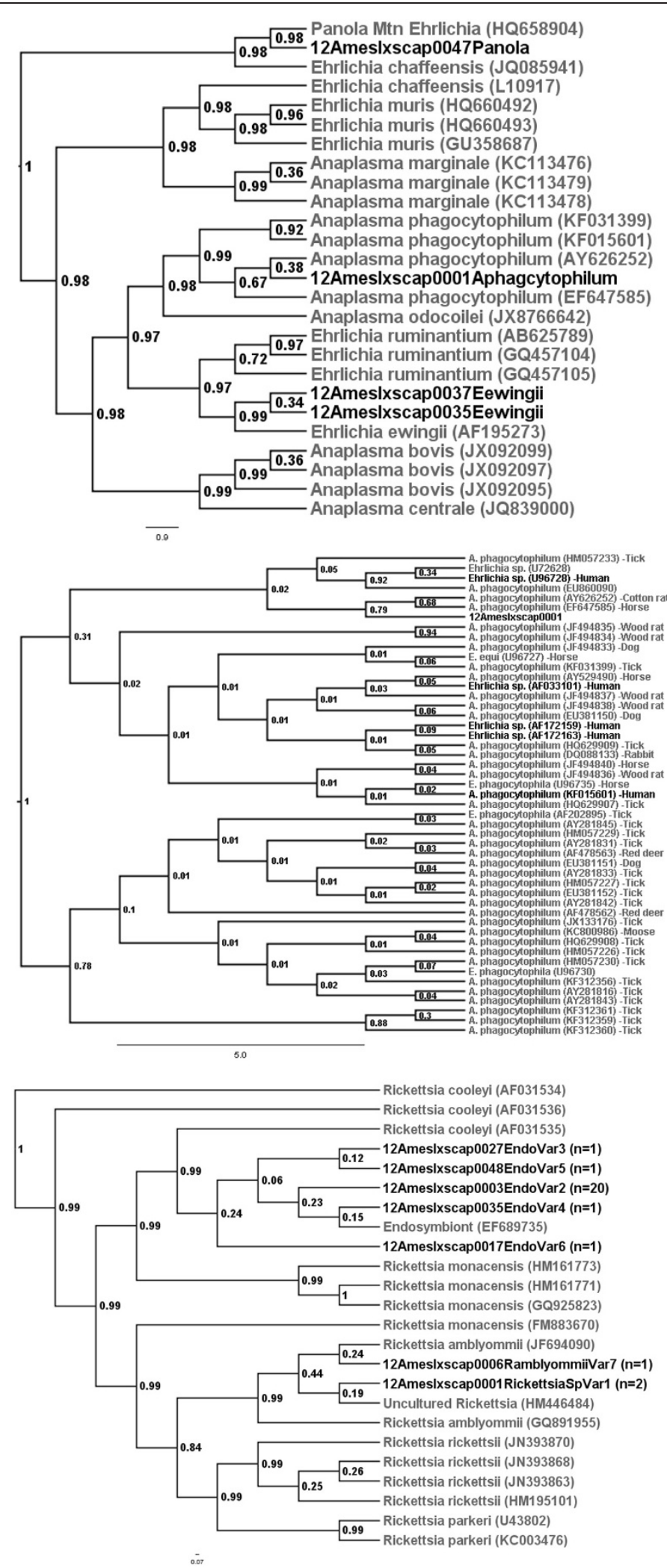

Figure 1 Bayesian phylogenetic relationships of 335 bp of groEL amplified from Ehrlichia (top), 300 bp of groEL amplified from Anaplasma (middle), and 378 bp of ompA amplified from Rickettsia species (bottom) identified in Ixodes scapularis collected at AMES compared to reference sequences from GenBank. 
Table 2 All four of the adult Ixodes scapularis PCR positive for Ehrlichia/Anaplasma (groEL) were also PCR positive with a Rickettsia species (ompA)

\begin{tabular}{|c|c|c|c|c|}
\hline \multicolumn{5}{|c|}{ Rickettsia and Ehrlichia species co-infections } \\
\hline \multirow{2}{*}{$\begin{array}{l}\text { ompA positive for Rickettsia } \\
\text { species (GenBank \#) }\end{array}$} & \multicolumn{3}{|c|}{ groEL positive for Ehrlichia species (GenBank \#) } & \multirow{2}{*}{$\begin{array}{l}\text { Ehrlichia (-) and } \\
\text { Rickettsia }+\end{array}$} \\
\hline & $\begin{array}{l}\text { Anaplasma phagocytophilum } \\
\text { (\# EF647585) }\end{array}$ & $\begin{array}{l}\text { Ehrlichia ewingii } \\
\text { (\# AF195273) }\end{array}$ & Panola Mtn. (\# HQ658904 ) & \\
\hline Rickettsia amblyommii (\#JF694090) & 0 & 0 & 0 & 1 \\
\hline Rickettsia spp. (\#HM446484) & 1 & 0 & 0 & 1 \\
\hline Endosymbiont (\#EF689735) & 0 & 2 & 1 & 21 \\
\hline Ehrlichia (+) and Rickettsia (-) & 0 & 0 & 0 & 0 \\
\hline
\end{tabular}

an Anaplasma or Ehrlichia species were also PCR positive (from here on defined as co-infected) with a Rickettsia species (Table 2). This was likely due to the endosymbiont being present in half of the ticks collected, and is not significantly greater than expected $(P=0.1256)$.

It is important to note that detection of $E$. ewingii and PME does not incriminate I. scapularis in transmission of either pathogen. Since all four Ehrlichia and Anaplasma-positive ticks were feeding on white-tailed deer, (Table 1) known amplifying reservoirs of these bacteria [37-39], adults collected from deer are likely positive from the blood meal of a potentially infected host. Host blood or tissue samples were not available for confirmation of infection. These ticks collected from hunter-killed white-tailed deer are not likely to transmit either of these pathogens since they already quested for their third host and are not very likely to encounter a human host in the field. Transmission of these bacteria to humans would most likely occur after the female tick acquires the pathogen from her host, but transovarial transmission does not occur with these bacteria [34]. Observations made during collections after deer were harvested noted some of these ticks leaving the hunter-killed host and actively questing towards the collectors, indicating these ticks are capable of contacting someone processing or handling the hunter-killed deer

Table 3 Infection status of adult Ixodes scapularis $(n=47)$ removed from individual white-tailed deer as determined by deer harvest number (id) ${ }^{1}$

\begin{tabular}{|c|c|c|c|c|c|c|c|c|}
\hline \multirow[t]{2}{*}{ Deer Id } & \multicolumn{2}{|l|}{ No. of Ticks } & \multicolumn{6}{|c|}{ Infection status of ticks by individual deer } \\
\hline & Neg. (\%) & Pos. (\%) & $\begin{array}{l}\text { Rickettsia } \\
\text { amblyommii }\end{array}$ & Rickettsia sp. & $\begin{array}{l}\text { Rickettsia } \\
\text { endosymbiont }\end{array}$ & $\begin{array}{l}\text { Anaplasma } \\
\text { phagocytophilum }\end{array}$ & $\begin{array}{l}\text { Ehrlichia } \\
\text { ewingii }\end{array}$ & $\begin{array}{l}\text { Ehrlichia Panola } \\
\text { Mountain }\end{array}$ \\
\hline
\end{tabular}

Ixodes scapularis collected from 2011 white-tailed deer

$\begin{array}{llllll}70 & 12 & 6(50 \%) & 6(50 \%) & 1 & 1 \\ 2 & 1 & 0(0 \%) & 1(100 \%) & - & 1 \\ 4 & 1 & 1(100 \%) & 0(0 \%) & - & - \\ 5 & 1 & 0(0 \%) & 1(100 \%) & - & - \\ 17 & 1 & 0(0 \%) & 1(100 \%) & - & - \\ 39 & 1 & 0(0 \%) & 1(100 \%) & - & -\end{array}$

Ixodes scapularis collected from 2012 white-tailed deer

\begin{tabular}{|c|c|c|c|c|c|c|c|c|}
\hline 123 & 13 & 7 (53.9\%) & $6(46.1 \%)$ & - & - & 6 & - & - \\
\hline 137 & 5 & $1(20 \%)$ & $4(80 \%)$ & - & - & 4 & - & 2 \\
\hline 156 & 3 & $2(66.7 \%)$ & $1(33.3 \%)$ & - & - & 1 & - & - \\
\hline 96 & 2 & $1(50 \%)$ & $1(50 \%)$ & - & - & 1 & - & - \\
\hline 110 & 2 & $0(0 \%)$ & $2(100 \%)$ & - & - & 2 & - & - \\
\hline 1210 & 2 & $0(0 \%)$ & $2(100 \%)$ & - & - & 2 & - & - \\
\hline 122 & 1 & $0(0 \%)$ & $1(100 \%)$ & - & - & 1 & - & - \\
\hline 94 & 1 & $1(100 \%)$ & $0(0 \%)$ & - & - & - & - & - \\
\hline 90 & 1 & $1(100 \%)$ & $0(0 \%)$ & - & - & - & - & - \\
\hline TOTAL & 47 & $20(42.6 \%)$ & $27(57.4 \%)$ & 1 & 2 & 24 & 1 & 2 \\
\hline
\end{tabular}

${ }^{1}$ Bolded deer identification numbers (identified as $2,137,1210$ ) had ticks that were PCR positive with more than one bacteria. Total numbers of infections exceed the number of positive ticks due to co-infected individuals. 
(i.e., hunters field-dressing the animal, taxidermists, personnel at check stations). Whether I. scapularis can transmit one or more of these pathogens in this scenario, leaving the killed host and moving towards the hunter, remains to be understood.

From the 15 harvested deer, a range of 1 to 13 I. scapularis were collected and PCR screened for bacteria (Table 3). Eight deer had only one tick, and three of those eight ticks were negative for all bacteria. Three deer, identified as 2, 137, and 1210, had ticks that were PCR positive for both a Rickettsia and a second bacteria (Anaplasma or Ehrlichia). One deer, deer 137, had five ticks removed from it and of those five ticks, two were PCR positive for E. ewingii, two were positive with a Rickettsia endosymbiont, and one was negative for all bacteria. This was also seen in deer 1210, where two ticks were collected and both were positive for a Rickettsia endosymbiont and only one was positive with PME. Finding Ehrlichia negative ticks and Ehrlichia positive ticks from the same host implies that those Ehrlichia positive ticks may not have acquired the pathogen from that specific deer, although all ticks testing positive for an Anaplasma or an Ehrlichia species were at least partially engorged.

Finding etiological agents that are pathogenic to humans (PME and E. ewingii) in I. scapularis merits additional studies surveying pathogen prevalence of other non-Borrelia bacteria in questing I. scapularis at AMES, both because of the risk of human exposure to disease agents, and to aid in accurate diagnosis of TBD cases in western Tennessee. The potential for blood-borne transmission of A. phagocytophilum is also notable as it is possible that hunters may come into contact with the agent during the processing of infected deer [40], though it has been suggested that the most common strain of $A$. phagocytophilum circulating in whitetailed deer may not be pathogenic to humans [36,41]. In this study, the Anaplasma sequence amplified from the tick was homologous to the AP-variant 1 strain, which is not currently considered a pathogen of humans.

Ixodes scapularis collections in the summer months are typically infrequent in the southeastern United States [17]. In the summers of 2012 and 2013, extensive collections using dragging and dry ice trapping collected over 17,000 ticks at AMES. This number included only one Ixodes nymph in 2012 and three adult females in 2013. Spring and winter collections (concurrent with deer and turkey hunting seasons) have not been undertaken during the peak collection time for adults of this species, so the human risk of encountering questing adult $I$. scapularis at AMES remains unknown, but may increase in a scenario where a hunter is processing a harvested deer. Collection of questing I. scapularis in their peak activity months should be undertaken to determine the overall encounter rates and relative risk rates in the southeast, especially since $I$. scapularis is more widespread than previously realized [13]; however, previous studies have not indicated a large active-questing population such as those populations observed in northern areas [17,42]. Because a delay in diagnosis can be fatal, continuing education of physicians in the diagnosis of TBD is critical especially in southwestern Tennessee, where $26 \%$ of all fatal RMSF cases occur $[17,43,44]$. Knowledge of the disease agents present in an area and the likelihood of human exposure can be helpful in making proper diagnoses and treatment decisions, and initiating appropriate measures to prevent human infection.

\section{Abbreviations}

AMES: Ames Plantation Research and Education Center; PME: Panola Mountain Ehrlichia; RMSF: Rocky Mountain Spotted fever; SFGR: Spotted fever group Rickettsia; TBD: Tick-borne diseases.

\section{Competing interests}

The authors declare that they have no competing interests.

\section{Authors' contributions}

$\mathrm{BMH}$ and $\mathrm{AEH}$ collected the specimens. SEM, BMH and DJP conducted the laboratory work; identified the ticks and screened them for each pathogen. SEM and RTF analyzed the data and constructed the manuscript. RTF and AEH conceived and designed the study and helped draft the manuscript. All authors read and approved the final manuscript.

\section{Acknowledgements}

We would like to thank Graham Hickling and Lauren Maestas in the department of Department of Forestry, Wildlife and Fisheries, University of Tennessee, Knoxville, Tennessee, USA for critical reading of the paper, and for assistance with tick identification, QPCR, and B. burgdorferi control. We would also like to thank Stephen Kania and Rupal Brahmbhatt in the Department of Comparative Medicine, University of Tennessee Veterinary Teaching Hospital, Knoxville, Tennessee, USA for assistance with the Borrelia and Babesia assays, and Abelardo Moncayo, Tennessee Department of Health, for contribution of E. chaffeensis and Rickettsia sp. controls. We would also like to acknowledge the Trustees of the Hobart Ames Foundation and thank those personnel with the Ames Plantation Research and Education Center, Grand Junction, Tennessee, USA especially Larry Teague, James Morrow, and Rick Carlisle for assistance with tick collection. Funding for this project was provided by University of Tennessee Hatch Project TEN00433 and by the American Kennel Club Canine Health Foundation Acorn Grant 01864-A

\section{Author details}

'Department of Entomology and Plant Pathology, University of Tennessee, 370 Plant Biotechnology Building 2505 E J Chapman Drive, Knoxville, TN, USA ${ }^{2}$ Department of Forestry, Fisheries, and Wildlife, University of Tennessee,

Tennessee and Ames Plantation, Grand Junction, Knoxville, Tennessee, USA.

Received: 24 October 2013 Accepted: 2 October 2014

Published online: 22 October 2014

\section{References}

1. Spach DH, Liles WC, Campbell GL, Quick RE, Anderson DE, Fritsche TR: Tick-borne diseases in the United States. N Engl J Med 1993, 329:936-947.

2. Piesman J, Mather TN, Dammin GJ, Telford SR III, Lastavica CC, Spielman A: Seasonal variation of transmission risk of Lyme disease and Human Babesiosis. Am J Epidemiol 1987, 126:1187-1189.

3. Piesman J: Transmission of Lyme disease spirochetes (Borrelia burgdorferi). Exp Appl Acarol 1989, 7:71-80.

4. Adelson ME, Rao RS, Tilton RC, Cabets K, Eskow E, Fein L, Occi JL, Mordechai E: Prevalence of Borrelia burgdorferi, Bartonella spp., Babesia microti, and Anaplasma phagocytophila in Ixodes scapularis ticks collected in northern New Jersey. J Clin Microbiol 2004, 42:2799-2801.

5. Dumler SJ, Madigan JE, Pusterla N, Bakken JS: Ehrlichiosis in humans: epidemiology, clinical presentation, diagnosis and treatment. Clin Infect Dis 2007, 45:45-51. 
6. Pritt BS, Sloan LM, HoangJohnson DK, Munderloh UG, Paskewitz SM, McElroy KM, McFadden JD, Binnicker MJ, Neitzel DF, Liu G, Nicholson WL, Nelson CM, Franson JJ, Martin SA, Cunningham SA, Steward CR, Bogumill K, Bjorgaard ME, Davis JP, McQuiston JH, Warshauer DM, Wilhelm MP, Patel R, Trivedi VA, Eremeeva ME: Emergence of a new pathogenic Ehrlichia species, Wisconsin and Minnesota, 2009. N Engl J Med 2011, 365:422-429.

7. Kramer VL, Randolph MP, Hui LT, Irwin WE, Gutierrez AG, Vugia DJ: Detection of the agents of human Ehrlichioses in Ixodid ticks from California. Am J Trop Med Hyg 1999, 60:62-65.

8. Holden K, Boothby JT, Anand S, Massung RF: Detection of Borrelia burgdorferi, Ehrlichia chaffeensis, and Anaplasma phagocytophilum in ticks (Acari:Ixodidae) from a coastal region of California. J Med Entomol 2003, 40:534-539.

9. Alekseev AN, Duvinina HV, Semenov AV, Bolshakov CV: Evidence of Ehrlichiosis agents found in ticks (Acari: Ixodidae) collected from migratory birds. J Med Entomol 2001, 38:471-474.

10. Kim C, Kim M, Park M, Park J, Chae J: Identification of Ehrlichia chaffeensis, Anaplasma phagocytophilum, and A. bovis in Haemaphysalis longicornis and Ixodes persulcatus ticks from Korea. Vector Borne Zoonotic Dis 2003, 3:17-26.

11. Williamson PC, Billingsley PM, Teltow GJ, Seals JP, Turnbough MA, Atkinson SF: Borrelia, Ehrlichia, and Rickettsia spp. in ticks removed from persons, Texas, USA. Emerg Infect Dis 2010, 16:441-446.

12. Diuk-Wasser MA, Gatewood Hoen A, Cislo P, Brinkerhoff R, Hamer SA, Rowland M, Cortinas R, Vourc'h G, Melton F, Hickling GJ, Tsao Jl, Bunikis J, Barbour AG, Kitron U, Piesman J, Fish D: Human risk of infection with Borrelia burgdorferi, the Lyme Disease Agent, in Eastern United States. Am J Trop Med Hyg 2012, 86:320-327.

13. Rosen ME, Hamer SA, Gerhardt RR, Jones CJ, Muller LI, Scott MC, Hickling GJ: Borrelia burgdorferi not detected in widespread Ixodes scapularis (Acari: Ixodidae) collected from white-tailed deer in Tennessee. J Med Entomol 2012, 49:1473-1480.

14. Moncayo AC, Cohen SB, Fritzen CM, Huang E, Yabsley MJ, Freye JD, Dunlap BG, Huang J, Mead DG, Jones TF, Dunn JR: Absence of Rickettsia rickettsii and occurrence of other Spotted Fever Group Rickettsiae in ticks from Tennessee. Am J of Trop Med Hyg 2010, 83:653-657.

15. Cohen SB, Yabsley MJ, Freye JD, Dunlap BG, Rowland ME, Huang J, Dunn JR, Jones TF, Moncayo AC: Prevalence of Ehrlichia chaffeensis and Ehrlichia ewingii in ticks from Tennessee. Vector-Borne Zoonotic Dis 2010, 10:435-440.

16. Tennessee Department of Health: Communicable Disease Interactive Data [Cited 07-30-13] http://health.state.tn.us/Ceds/WebAim/.

17. Stromdahl EY, Hickling GJ: Beyond Lyme: etiology of tick-borne human diseases with emphasis on the south-eastern United States. Zoonosis Public Health 2012, 59:48-64.

18. Keirans JE, Litwak TR: Pictorial key to the adults of hard ticks, family Ixodidae (Ixodida: Ixodoidae), east of the Mississippi river. J Med Entomol 1989, 26:435-448.

19. Black WC IV, Piesman J: Phylogeny of hard- and soft-tick taxa (Acari: Ixodida) based on mitochondrial 16S rDNA sequences. Proc Natl Acad Sci U S A 1994, 91:10034-10038.

20. Takano A, Ando S, Kishimoto T, Fujita H, Kadosaka T, Nitta Y, Kawabata H, Watanabe $\mathrm{H}$ : Presence of a novel Ehrlichia sp. in Ixodes granulatus found in Okinawa, Japan. Microbiol Immunol 2009, 53:101-106.

21. Massung RF, Slater K, Owens JH, Nicholson WL, Mather TN, Solberg VB, Olson JG: Nested PCR assay for detection of Granulocytic Ehrlichiae. J Clin Microbiol 1998, 36:1090-1095

22. Meinkoth J, Kocan AA, Whitworth L, Murphy G, Fox JC, Woods JP: Cats surviving natural infection with Cytauxzoon felis: 18 cases (1997-1998) J Vet Intern Med 2000, 14:521-525.

23. Wodecka B, Leońska A, Skotarczak B: A comparative analysis of molecular markers for the detection and identification of Borrelia spirochaetes in Ixodes ricinus. J Med Microbiol 2010, 59:309-314.

24. Yang J, Liu Z, Guan G, Che R, Niu Q, Li Y, Liu J, Ma M, Ren Q, Liu A, Luo J, Yin $\mathrm{H}$ : Evaluation of molecular methods for detection of Borrelia burgdorferi senu lato in ticks. Diagn Microbiol Infect Dis 2012, 73:80-83.

25. Courtney JW, Kostelnik LM, Zeidner NS, Massung RF: Multiplex real-time PCR for detection of Anaplasma phagocytophilum and Borrelia burgdorferi. J Clin Microbiol 2004, 42:3164-3168.

26. Clark KL, Leydet B, Hartman S: Lyme borreliosis in human patients in Florida and Georgia, USA. Int J Med Sci 2013, 10:915-931.
27. Eremeeva M, Yu X, Raoult D: Differentiation among spotted fever group rickettsiae species by analysis of restriction fragment length polymorphism of PCR-amplified DNA. J Clin Microbiol 1994, 32:803-810.

28. Drummond AJ, Suchard MA, Xie D, Rambaut A: Bayesian phylogenetics with BEAUti and the BEAST 1.7. Mol Biol Evol 2012, 29:1969-1973.

29. Plantonov AE, Karan LS, Kolyasnikova NM, Makhneva NA, Toporkova MG, Maleev W, Fish D, Krause PJ: Humans infected with relapsing fever spirochete Borrelia miyamotoi, Russia. Emerg Infect Dis 2011, 17:1816-1823.

30. Krause PJ, Narasimhan S, Wormser GP, Rollend L, Fikrig E, Lepore T, Barbour A, Fish D: Human Borrelia miyamotoi infection in the United States. N Engl J Med 2013, 368:291-293.

31. Raoult D: A new rickettsial disease in the United States. Clin Infect Dis 2004, 38:812-813.

32. Azad AF, Beard CB: Rickettsial pathogens and their arthropod vectors. Emerg Infect Dis 1998, 4:179-186.

33. Ammerman NC, Swanson Kl, Anderson JM, Schwartz TR, Seaberg EC, Glass GE, Norris DE: Spotted-Fever Group Rickettsia in Dermacentor variabilis, Maryland. Emerg Infect Dis 2004, 10:1478-1481.

34. Stromdahl EY, Vince MA, Billingsley PM, Dobbs NA, Williamson PC: Rickettsia amblyommii infecting Amblyomma americanum larvae. Vector Borne Zoonotic Dis 2008, 8:15-24.

35. Macaluso KR, Sonenshine DE, Ceraul SM, Azad AF: Rickettsial infection in Dermacentor variabilis (Acari: Ixodidae) inhibits transovarial transmission of a second Rickettsia. J Med Entomol 2002, 39:809-813.

36. Massung RF, Priestley RA, Miller NJ, Mather TN, Levin ML: Inability of a variant strain of Anaplasma phagocytophilum to infect mice. J Infect Dis 2003, 188:1757-1763.

37. Yabsley MJ, Varela AS, Tate CM, Dugan VG, Stallknecht DE, Little SE, Davidson WR: Ehrlichia ewingii infection in white-tailed deer (Odocoileus virginianus). Emerg Infect Dis 2002, 8:668-671.

38. Yabsley MJ, Loftis AD, Little SE: Natural and experimental infection of white-tailed deer (Odocoileus virginianus) from the United States with an Ehrlichia sp. closely related to Ehrlichia ruminantium. J Wildl Dis 2008, 44:381-387

39. Varela-Stokes AS: Transmission of bacterial agents from lone star ticks to white-tailed deer. J Med Entomol 2007, 44:478-483.

40. Bakken JS, Krueth JK, Lund T, Malkovich D, Asanovich K, Dumler JS: Exposure to deer blood may be a cause of Human Granulocytic Ehrlichiosis. Clin Infect Dis 1996, 23:198.

41. Dugan VG, Yabsley MJ, Tate CM, Mead DG, Munderloh UG, Herron MH Stallknecht DE, Little SE, Davidson WR: Evaluation of white-tailed deer (Odocoileus virginianus) as natural sentinels for Anaplasma phagocytophilum. Vector-Borne Zoonotic Dis 2006, 6:192-207.

42. Harmon JR, Hickling GJ, Scott MC, Jones CJ: Evaluation of 4-poster acaricide applicators to manage tick populations associated with disease risk in a Tennessee retirement community. J Vector Ecol 2011, 36:404-410.

43. Adjemian JZ, Krebs J, Mandel E, McQuiston J: Spatial clustering by disease severity among reported Rocky Mountain spotted fever cases in the United States, 2001-2005. Am J Trop Med Hyg 2009, 80:72-77.

44. Dantas-Torres T: Rocky Mountain spotted fever. Lancet Infec Dis 2007, 7:724-732.

doi:10.1186/s13071-014-0473-y

Cite this article as: Mays et al.: Prevalence of five tick-borne bacterial genera in adult Ixodes scapularis removed from white-tailed deer in western Tennessee. Parasites \& Vectors 2014 7:473. 